\title{
Mental Health and Conflict in Nigeria: An Overview
}

\author{
Miracle Ayomikun Adesina ${ }^{1,2,3,4,5 *}$, Temilade Adesanya ${ }^{2}$, Isaac Iyinoluwa Olufadewa ${ }^{1,6}$
}

\author{
${ }^{1}$ Slum and Rural Health Initiative Research Academy, NIGERIA \\ ${ }^{2}$ College of Medicine, University of Ibadan, Ibadan, NIGERIA \\ ${ }^{3}$ Universal Care for Africa Foundation, St Louis, USA \\ ${ }^{4}$ Cephas Health Research Initiative, Ibadan, NIGERIA \\ ${ }^{5}$ Mental and Oral Health Development Organization, Kebbi, NIGERIA \\ ${ }^{6}$ Pan African University of Life and Earth Sciences Institute, PAULESI, Ibadan, NIGERIA \\ *Corresponding Author: miracleadesina5@gmail.com
}

Citation: Adesina, M. A., Adesanya, T. and Olufadewa, I. (2020). Mental Health and Conflict in Nigeria: An Overview. European Journal of Environment and Public Health, 4(1), em0038. https://doi.org/10.29333/ejeph/7806

ARTICLE INFO

Received: 22 Jan. 2020

Accepted: 25 Jan. 2020

\begin{abstract}
Nigeria, the giant of Africa, is a West African country with a total land area of 910,770 square kilometers and a population of 198,778,607 people. She is made up of diverse people based on ethnic group, language, religion, etc. The diversities present in the country, however, have been a major cause of conflicts. Conflict in Nigeria has resulted in the death, displacement, sexual violations, injuries, disabilities among others, of the population affected. Zones commonly affected in Nigeria are the north east (due to Boko Haram insurgency), north central(territorial dispute between nomadic farmers and the community dwellers compounded by ethnoreligious issues) and south south (high unemployment rate despite the presence of a mineral resource [petroleum] and ecological degradation due to oil spillage) geopolitical zones. Children, victims of sexual violence, families that lost their loved ones, refugees and internally displaced people are the main victims of mental illness in conflicting regions in Nigeria. Individuals affected by conflict could present with varying mental health conditions such as post-traumatic stress disorders (PTSD), anxiety disorder, depression, substance misuse, psychosis, anti-social behaviours, somatic symptoms such as headaches, non-specific pains or discomfort in torso and limbs, dizziness, weakness, and fatigue, etc. This study presented the mental health status of the individuals in these conflict zones. Authors appeal that their recommendations be applied to reduce the burden of mental illness in the conflict zones in Nigeria.
\end{abstract}

Keywords: mental health, conflict, northeast Nigeria

\section{INTRODUCTION}

Nigeria, the giant of Africa, is a West African country with a total land area of 910,770 square kilometers and a population of 198,778,607 people (Worldometers, 2019). Nigeria is made up of diverse people based on ethnic group, language, religion, etc. (Findlay, 2019). There are over 250 ethnic groups and languages in Nigeria, the major ones are the Hausa and Fulani in the north, the Yoruba in the southwest and the Igbo in the southeast (Encylopedia Britannica, 2019). The major religions practiced are Christianity, Islamic and African traditional religion (New World Encylopedia, 2018). The diversities present in the country have been a major cause of conflicts (Akpan, 2007).

Conflict is an interactive process manifested by incompatibility, disagreement or dissonance within or between social entities (Gabriel, 2018). Conflict in Nigeria has resulted in the death, displacement, sexual violations, injuries, disabilities among others, of the population affected
(Integrated Regional Information Networks, 2012). Zones commonly affected in Nigeria are the north east, north central and south south geopolitical zones (Suleman, 2016). The north east comprises of six states and has the highest number of recorded conflict compared to other zones over the last eight years. The cause of conflict in this zone is majorly due to Boko Haram insurgency (Azad, Crwaford and Kaila, 2018). The actions of this group and the resulting military operations have reportedly affected nearly fifteen million people between 2009 and 2017 (Adesina, Kanmodi and Merrick, 2019; Obi, Uzochukwu and Chukwuemeka, 2018).

Conflict in the north central geopolitical zone is caused by territory dispute between the nomadic farmers and the community dwellers, with ethno-religious issues compounding the conflict (Adesina and Kanmodi, 2019a; Obi, Uzochukwu and Chukwuemeka, 2018; Osimen, Oyewole and Akinwumi, 2017). The south south zone is the major source of petroleum (black gold) in Nigeria. This zone however suffers from ecological degradation as a result of oil spillage (Albert, Amarantunga and Haigh, 2018; Osuagwu and Olaifa, 2018). 
The zone is conflicted due to high unemployment rate despite the presence of a mineral resource, political tensions among others (Ibaba, 2008). This has resulted in high criminal and bandit activities, oil pipelines explosions, abduction and robberies (Azad, Crwaford and Kaila, 2018).

\section{IMPLICATIONS OF CONFLICT ON MENTAL HEALTH}

The mental health of individuals or communities is usually affected during or after conflicts. Individually, people react to conflicts in various ways depending on the nature and severity of conditions they are faced with (Virga et al., 2014). The age, maturity, sex and occupation of the individual also affects the way they respond to conflict. Children, victims of sexual violence, families that lost their loved ones, refugees and internally displaced people are the main victims of mental illness (Pritchard and Choonara, 2017). Individuals affected by conflict could present with varying mental health conditions such as post-traumatic stress disorders (PTSD), anxiety disorder, depression, substance misuse, psychosis, anti-social behaviours, somatic symptoms such as headaches, nonspecific pains or discomfort in torso and limbs, dizziness, weakness, and fatigue, etc (Adesina and Kanmodi, 2019b; Bisson et al., 2015; McDonald, 2007; Murthy and Lakshminarayana, 2006).

Ten mental health specialists groups in northeast Nigeria conducted 294 outreach sessions from April to June, 2018. During the outreach 5031 individuals in selected primary health care facilities and internally displaced peoples camp health facilities in north east Nigeria were treated for different mental illnesses (MHPSS Nigeria, 2018). A total of 1276 individuals had severe emotional disorders, 1229 had seizure disorders associated with psychological distress, 925 medically unexplained somatic complaints, 774 had psychotic disorders, 349 had substance use disorder and 337 had other complaints (MHPSS, 2018).

A study was conducted in north central Nigeria (Jos) among individuals who witnessed ethno-religious violence. This study showed a significant association between violence and post-traumatic stress disorder (PTSD) (Tagurum et al., 2014). Majority (68.1\%) of the participants experienced constant watchfulness and were easily startled, $67.6 \%$ were in denial and avoidance of thoughts of the crisis, $52.9 \%$ experienced numbness and detachment from surroundings and $42.2 \%$ experienced recurring nightmares (Tagurum et al., 2014). In another study carried out among trauma victims in north central Nigeria (Dogonahawa community, Plateau state) among 266 participants, $47 \%$ being head of households and $53 \%$ being dependants. $45.2 \%$ of the head of households and $28.6 \%$ of dependents had depression (Taru et al., 2018).

In Nigeria, as of December 2018, 2,026,602 people were internally displaced (International Organization for Migration, 2018). This is majorly due to conflicts especially those caused by the Boko Haram sect (The Guardian, 2012). These individuals are therefore homeless and have to endure the conditions present in the camps set up for them (Obi and Eboreime, 2017). The crimes, conflicts and the conditions of the camps can put any individual in emotional stress and exposure to the varying mental health conditions (Morina et al., 2018).

Women and girls in north east Nigeria are sexually assaulted by militia of the Boko Haram sect (Adesina, Kanmodi and Merrick, 2019). These women and girls do come down with social isolation, depression, suicidal ideation and suicide (Read, 2017). Children at their young age are recruited to become members of the Boko Haram militia (The Readers Bureau, 2014). They can become affected with mental illness especially because of the rigor and aggressiveness of military and terrorism warfare. Children who are victims of conflicts in any region of Nigeria also suffer from mental illness (Pitchard and Choonara, 2017). A study conducted in north east Nigeria showed that the military personnel involved in the conflict zones have high likelihood of developing post-traumatic stress disorder and avoidance symptom (Dami et al., 2018).

\section{CONCLUSION}

Nigeria's diversities have been the cause of conflicts which has resulted in the death, displacement, sexual violations, injuries, disabilities among others, of the population affected. Of the six geopolitical zones in Nigeria, three: north east (Boko Haram insurgency), north central (territorial dispute between nomadic farmers and the community dwellers compounded by ethno-religious issues) and south south (high unemployment rate despite the presence of a mineral resource [petroleum] and ecological degradation due to oil spillage) are majorly affected. This study presented the mental health status of the population inhabiting this zone. Appropriate recommendations to improve the mental health status of the populace inhabiting these zones were presented.

\section{RECOMMENDATION}

It's essential that psychological needs of Nigerians should be prioritized especially those in conflict zones. Therefore, it is essential that;

- Primary health care providers are trained to recognize and manage common mental health conditions.

- Institutions addressing mental health of the conflict affected population should not only focus on the major cities. The safe rural regions should also be visited.

- More studies are done to determine the prevalence of various mental health conditions in the conflict zones.

- Individuals living in conflict zones are trained on how to handle and care for people in the community that have been affected directly or indirectly by conflict, rather than stigmatizing them. 


\section{REFERENCES}

Adesina, M. A. and Kanmodi, K. K. (2019a). Boko Haram terrorism in Nigeria. In Adesina MA, Kanmodi KK, J Merrick (Eds). The Boko Haram terror: Adversary to the wellbeing of Nigerian kids (pp. 47-70). New York, NY: Nova Science.

Adesina, M. A. and Kanmodi, K. K. (2019b). Boko Haram terrors: Impacts on the Nigerian child. In Adesina MA, Kanmodi KK, J Merrick (Eds). The Boko Haram terror: Adversary to the wellbeing of Nigerian kids (pp. 71-86). New York, NY: Nova Science.

Adesina, M. A., Kanmodi, K. K. and Merrick, J. (2019). The Boko Haram terror: Adversary to the wellbeing of Nigerian kids. New York, NY: Nova Science.

Akpan, W. (2007). Lessons from the Niger Delta crisis. Available at: https://www.accord.org.za/ajcr-issues/\%EF\% BF\%BCethnic-diversity-and-conflict-in-nigeria/

Albert, O. N., Amarantunga, D. and Haigh, R. P. (2018). Evaluation of the impacts of oil spill disaster on communities and its influence on restiveness in Niger Delta, Nigeria. Procedia Engineering, (212), 1054-1061. https://doi.org/10.1016/j.proeng.2018.01.136

Azad, A., Crawford, E. and Kaila, H. (2018). Conflict and violence in Nigeria. Nigeria: The World Bank \& National Bureau of Statistics, Nigeria. Preliminary Draft Report. Available at: https://www.google.com/url?sa=t\&rct=j\&q= \&esrc $=$ s \& source=web \&cd=1 \&cad=rja \&uact $=8$ \&ved $=2$ ahU KEwjz4fO645XgAhVyQhUIHYrODQwQFjAAegQICRAC\&u rl=http\%3A\%2F\%2Fwww.nigerianstat.gov.ng\%2Fnada\%2F index.php\%2Fcatalog\%2F55\%2Fdownload\%2F503\&usg=A OvVaw3ItJBt22z7oETnP-4yzQf7

Bisson, J. I., Cosgrove, S., Lewis, C. and Roberts, N. P. (2015). Post-traumatic stress disorder. BMJ. https://doi.org/10.1136/bmj.h6161

Dami, B. E., James, A., Zabairu, D., Karick, H. and Dakwak, S. (2018). Combat exposure and PTSD among military combatants in North East Nigeria. J Psychol Clin Psychiatr, 9(4), 400-404. https://doi.org/10.15406/jpcpy.2018.09. 00558

Encyclopedia Britannica. (2019). Nigeria. Available at: https://www.britannica.com/place/Nigeria

Findlay, J. (2019). Largest ethnic groups in Nigeria, World Atlas. Available at: https://www.worldatlas.com/articles/ largest-ethnic-groups-in-nigeria.html

Gabriel, E. (2018). Farmers/Fulani community synergises to foster peace/unity. Available at: https://eadership.ng/ 2018/10/14/farmers-fulani-community-synergise-tofoster-peace-unity/

Ibaba, I. S. (2008). Alienation and militancy in the Niger Delta: Hostage taking and the dilemma of the Nigerian state. Afric J Confl Resolut, 8(2), 11-34. https://doi.org/10.4314/ ajcr.v8i2.39424

Integrated Regional Information Networks. (2012). Timeline of Boko Haram attacks and related violence. Available at: http://www.irinnews.org/news/2012/01/20
International Organization for Migration. (2019). NigeriaIOM's displacement tracking matrix. Available at: https://displacement.iom.int/nigeria

McDonald, G. (2007). Mental health consequences of long term conflict. BMJ, 334(7604), $1121-1122$. https://doi.org/10.1136/bmj.39225.539803.80

Mental Health and Psychological Support (MHPSS), Nigeria. (2018). Quarterly update April - June 2018. Available at: https://reliefweb.int/sites/reliefweb.int/files/resources/M HPSS\%20SWG\%20QUARTELY\%20-\%20Q202018\%20\%20Updated.Large_pdf

Morina, N., Akhtar, A., Barth, J. and Schnyder, U. (2018). Psychiatric disorders in refugees and internally displaced persons after forced displacement: A systematic review. Front Psychiatry, 9, 433. https://doi.org/10.3389/fpsyt. 2018.00433

Murthy, R. S. and Lakshminarayana, R. (2006). Mental health consequences of war: a brief review of research findings. World Psychiatry, 5(1), 25-30.

New World Encyclopedia. (2018). Nigeria. Available at: http://www.newworldencyclopedia.org/entry/Nigeria

Obi, D., Uzochukwu, C. C. and Chukwuemeka, O. D. (2018). Politics of herdsmen attack and its socio-economic implication in Nigeria. Euro J Political Sci Stud, 1(2). https://doi.org/10.5281/zenodo.1312504

Obi, F. A. and Eboreime, E. (2017). How Boko Haram is devastating health services in North-East Nigeria. Available at: www.theconversation.com/how-boko-haram-isdevastating-health-services-in-north-east-nigeria-65751

Osimen, G. U., Oyewole, O. O. and Akinwunmi, A. A. (2017). Fulani Herdsmen and rural communities/farmers conflict in Nigeria. J Soc Sci Hum Res, 2(6), 72-89.

Osuagwu, E. S. and Olaifa, E. (2018). Effects of oil spill on fish production in the Niger Delta. PLoS ONE, 13(10), e0205114. https://doi.org/10.1371/journal.pone.0205114

Pritchard, E. and Choonara, I. (2017). Armed conflict and child mental health. BMJ Paediatrics Open, 1(1), 1-2. https://doi.org/10.1136/bmjpo-2017-000087

Read, J. (2017). Sexual Violence and the Boko Haram crisis in north-east Nigeria. Available at: https://odihpn.org/ magazine/sexual-violence-and-the-boko-haram-crisis-innorth-east-nigeria/

Suleiman, A. (2016). Boko Haram insurgency, Niger Delta militancy and the manifestation of corruption. Available at: https://www.vanguardngr.com/2016/06/boko-haraminsurgency-niger-delta-militancy-manifestationcorruption/

Tagurum, Y. O., Chirdan, O. O., Obindo, T., Bello, D. A., Afolaranmi, O. T., Hassan, Z. I. and Yilgwan, C. (2014). Prevalence of violence and symptoms of post-traumatic stress disorder among victims of ethno-religious conflict in Jos. Nigeria. J Psychiatry, 15(18), 178. https://doi.org/10.4172/Psychiatry.1000178 
Taru, M. Y., Audu, M. D., Philip, T. F., John, D. F., Yushau, A. A., Nnaemeka, C. N. and Bamidele, L. I. (2018). Armed conflict and depression among heads of households in Dogonahawa, North-Central Nigeria: Prevalence and correlates. Open J Depression, 7, 17-30. https://doi.org/10.4236/ojd.2018.72002

The Guardian (2012). Boko Haram attacks-timeline. Available at: https://www.theguardian.com/world/2012/sep/25/boko -haram-timeline-nigeria
The Readers Bureau (2014). Boko haram- Western Education is forbidden! Available at: https://thereadersbureau.com/ boko-haram-western-education-is-forbidden-2/

Virga, D., CurSeu, P. L., Maricutoiu, L., Sava, F. A., Macsinga, I. and Magurean, S. (2014). Personality, relationship conflict, and teamwork-related mental models. PLOS ONE 9(12), e116425. https://doi.org/10.1371/journal.pone. 0110223

Worldometers. (2019). Nigeria Population. Available at: www.worldometers.info/world-population/nigeriapopulation/ 